\title{
Az elhízás kezelése és megelőzése: táplálkozás, testmozgás, orvosi lehetőségek
}

\author{
Hazai szakmaközi ajánlás
}

\author{
Rurik Imre dr. ${ }^{1, a, b}$ - Apor Péter dr. ${ }^{7, c}$ - Barna Mária dr. ${ }^{2, a}$ \\ Barna István dr. ${ }^{3, \mathrm{~d}, \mathrm{e}, \mathrm{f}}$ - Bedros J. Róbert dr., ${ }^{4, \mathrm{~g}}$ - Kempler Péter dr. ${ }^{3, \mathrm{~h}}$ \\ Martos Éva dr. ${ }^{5, a, c}$. Mohos Elemér dr. ${ }^{6, b}$. Pavlik Gábor dr. ${ }^{7, c}$ \\ †Pados Gyula dr., a, g . Pucsok József dr. ${ }^{\text {b, } c}$ \\ Simonyi Gábor dr., ${ }^{4, g}$ - Bíró György dr. ${ }^{2, a}$
}

${ }^{1}$ Debreceni Egyetem, Általános Orvostudományi Kar, Családorvosi és Foglalkozásegészségügyi Tanszék, Debrecen

${ }^{2}$ Semmelweis Egyetem, Egészségtudományi Kar, Alkalmazott Egészségtudományi Intézet,

Dietetikai és Táplálkozástudományi Tanszék, Budapest

${ }^{3}$ Semmelweis Egyetem, Általános Orvostudományi Kar, Belgyógyászati és Onkoterápiás Klinika, Budapest

${ }^{4}$ Szent Imre Egyetemi Oktatókórház, Országos Obezitológiai Centrum, Budapest

${ }^{5}$ Testnevelési Egyetem, Sport-táplálkozástudományi Központ, Budapest

${ }^{6}$ Veszprém Megyei Csolnoky Ferenc Egyetemi Oktató Kórház,

Általános, Ér- és Metabolikus Sebészeti Centrum, Veszprém

${ }^{7}$ Testnevelési Egyetem, Egészségtudományi és Sportorvosi Tanszék, Budapest

${ }^{a}$ Magyar Táplálkozástudományi Társaság; 'Magyar Elhízástudományi Társaság; 'Magyar Sportorvos Társaság;

${ }^{\mathrm{d}}$ Magyar Életmód-orvostani Társaság; ${ }^{\mathrm{e}}$ Magyar Hypertonia Társaság; ${ }^{\mathrm{f}}$ Magyar Nephrologiai Társaság;

${ }^{\mathrm{g}}$ Magyar Obezitológiai és Mozgásterápiás Társaság; ${ }^{\mathrm{h}}$ Magyar Diabetes Társaság

\begin{abstract}
Az elhízás és következményes megbetegedései fontos népegészségügyi problémát jelentenek hazánkban is. Kezelése komoly szakmai kihívás, ugyanakkor prevenciója eredményesebb lehet. Az elhízott betegekkel leggyakrabban találkozó háziorvosok, más szakorvosok és egészségügyi szakemberek részéről nagy igény van egy viszonylag rövid, áttekinthető, naprakész gyakorlatias útmutatóra. A különböző orvosszakmai társaságokban tevékenykedő, évtizedes szakmai tapasztalatokkal rendelkező szerzők összefoglalják tudományosan megalapozott, bizonyítékokon alapuló ismereteiket. Az elhízás kezelését lépcsőzetesen célszerú megkezdeni, előtte felmérve a beteg motivációját, általános állapotát, lehetőségeit. A szerzők leírják az energiaszükséglet meghatározásával, az étrenddel és a fizikai aktivitás megtervezésével kapcsolatos alapvető szempontokat. Felsorolják a hazánkban elérhető gyógyszereket és metabolikus sebészeti beavatkozásokat, az életmódi támogatás igényét. Az elhízás megelőzésében az élet első 1000 napjának táplálkozása, a későbbiekben a szülői minta a meghatározó. Sok kihasználatlan lehetősége van a háziorvosok, a lakóközösségek, az állami szervek koordinált együttmúködésének, helyi kezdeményezéseknek. Az elhízás betegségként való meghatározása egyaránt igényel egészségpolitikai és kormányzati támogatást, az elhízottak ellátására szakosodott multidiszciplináris centrumok számának és kompetenciájának növelését.
\end{abstract}

Orv Hetil. 2021; 162(9): 323-335.

Kulcsszavak: elhízás, fizikai aktivitás, kezelés, megelőzés, táplálkozás, túlsúly

\section{Therapy and prevention of obesity: nutrition, physical activity and medical treatment}

\section{Recommendations of Hungarian professionals}

Obesity and related morbidities have a high public health impact in Hungary. The treatment is a challenge, but prevention seems more effective. General practitioners, other specialists and health care professionals who are treating obese persons require short, summarized, updated and practical guideline. Hungarian medical professionals of different scientific societies, having decennial practices, are summarizing their evidence-based knowledge. Obesity management requires step by step approach, evaluating previously the general health condition, motivation and options 
of the patients. The measurement of energy requirement, planning of diet and physical activities, available surgical methods and medications are described in detail with life style and mental support needed. The most important period in the prevention of obesity is the first 1000 days from conception. Other significant factors are the life style habits of the parents. Proper obesity prevention requires better coordination of primary health care, community and governmental activities. Obesity should be defined as morbidity, therefore stronger governmental support and more health-policy initiatives are needed, beside increasing number and developing of multidisciplinary centres.

Keywords: nutrition, obesity, overweight, physical activity, prevention, treatment

Rurik I, Apor P, Barna M, Barna I, Bedros JR, Kempler P, Martos É, Mohos E, Pavlik G, †Pados Gy, Pucsok J, Simonyi G, Bíró Gy. [Therapy and prevention of obesity: nutrition, physical activity and medical treatment. Recommendations of Hungarian professionals]. Orv Hetil. 2021; 162(9): 323-335.

(Beérkezett: 2020. augusztus 4.; elfogadva: 2020. szeptember 17.)

\section{Rövidítések}

$\mathrm{BMI}=($ body mass index $)$ testtömegindex $;$ DASH $=($ Dietary Approaches to Stop Hypertension) étrend a magas vérnyomás megállításának elősegítésére; DEXA = (dual-energy X-ray absorptiometry) kettős energiájú röntgenabszorpciometria; E-Alap = Egészségbiztosítási Alap; EASO = (European Association for the Study of Obesity) Európai Elhízástudományi Társaság; GDP $=$ (gross domestic product) bruttó hazai termék; GLP = (glucagone-like peptide) glükagonhoz hasonló peptid; HDL = (high-density lipoprotein) magas sürüségű lipoprotein; LDL = (low-density lipoprotein $)$ alacsony sưrúségú lipoprotein; LGSR = (laparoscopic gastric sleeve resection) laparoszkópos gyomorhüvely-reszekció; LRYGB = (laparoscopic Roux-en-Y gastric bypass) laparoszkópos Roux-en-Y gyomorbypass; SGLT $=$ (sodium/glucose cotransporter $)$ nátrium-glükóz kotranszporter; USA = (United States of America $)$ Amerikai Egyesült Államok; WHO = (World Health Organization) Egészségügyi Világszervezet

Egészségügyi körökben és a lakosság egyre nagyobb részében is közismert, hogy a legtöbb megbetegedés kialakulásában a táplálkozás fontos etiológiai tényező, amely befolyásolhatja a betegségek kimenetelét, kezeléseik eredményességét. Az egészséges táplálkozásra vonatkozó tudományos ismeretek folyamatosan bővülnek, a szakemberek újabb felfedezéseket, felismeréseket publikálnak, bár nem mindig ugyanazokat a konzekvenciákat levonva.

A lakosság ismereteinek forrása az utóbbi évtizedben nagyságrendekkel bővebb lett, elsősorban az internet széles körû elterjedése következtében, ahol sokkal nagyobb számban érhető́k el tudományosan megalapozatlan, esetenként káros információk, a leggyakrabban kereskedelmi, üzleti háttérrel, gyakran „csodás” fogyókúrákat is ajánlva.

$\mathrm{Az}$ orvostudomány ismereteinek fejlődésével a hazai orvosképzés megpróbál lépést tartani, ugyanakkor a táplálkozásra, az egyes megbetegedések táplálkozási konzekvenciáira vonatkozó ismeretek oktatására sajnálatosan kevés idő és figyelem jut, ennek hiányát mind a kollégák, mind betegeik megérzik. A helyzet hasonló a fizikai akti- vitás, a testmozgás területén is, bár a prevenció fontosságáról az utóbbi években már többet hallanak a medikusok.

A gyakorló orvosnak kevés ideje van szürni a világhálón terjengő, áttekinthetetlen információhalmazt, szembesülnie kell betegei innen származó, szakmailag nem feltétlenül megalapozott ismereteivel, igényeivel. Különösen a háziorvos tanácstalan, hiszen sem dietetikai, sem sportszakemberi képzettsége nincs, szerencsés esetben ismer és tud ajánlani valakit vagy valamilyen szolgáltatást a beteg lakókörnyezetében. A szervezet energiaigényéról vannak ismeretei, de a táplálékkal bevitt egyes élelmiszerek alkotóiról, a fizikai aktivitás (sportolás, mozgásformák) energiafelhasználásáról már ritkábban. Bár terjednek a gyógyszeres és mútéti kezelések is, rendszerezett információt ezekről alig kap.

A hazai orvosszakmai társaságok hagyományosan kiadnak terápiás ajánlásokat bizonyos betegségcsoportok esetében, de ezek gyakran késve, többnyire opcionálisan jutnak el a háziorvosokig, terjedelmük miatt nehezen használhatók. Azok a szakorvosok, akik csak saját szakterületük irodalmát követik, szintén tájékozatlanok maradhatnak. Az utóbbi két évtizedben a magyar kardiovaszkuláris konszenzus konferenciák ajánlásai közismertté váltak, és szinte minden érdeklődő kollégához eljutottak.

Napjainkban Magyarországon a vezető halálokok a cardiovascularis kórképek és a daganatos megbetegedések. Mindkét csoportban jelentős etiológiai tényező az elhízás, így ennek elsősorban a megelőzése, de - ha már kialakult - akkor a kezelése is fontos népegészségügyi érdek [1]. Ez célként szerepel a nagy népbetegségek hazai kezelési ajánlásaiban is $[2,3]$.

\section{Célkitüzés}

Munkánk célja, hogy a különböző orvosszakmai társaságokban tevékenykedő, évtizedes szakmai tapasztalatokkal rendelkező szerzők összefoglalják tudományosan megalapozott, bizonyítékokon alapuló ismereteiket. 
Ezekből merítve az orvosok, egészségügyi szakemberek könnyen megérthető, praktikus tanácsokat adhatnak nemcsak a már betegeknek, hanem a primer vagy szekunder prevenciót igénylőknek is, megfelelő transzlációt biztosítva a kutatásokból a mindennapi gyakorlatba.

Ez a munka nem tekinthető hivatalos szakmai irányelvnek, mert más módszertannal és más szerkezetben készült, evidenciaszintek meghatározása nélkül fogalmaz meg tudományosan megalapozott ajánlásokat (grade of recommendation), legfontosabb célként kitüzve a rövidséget és az áttekinthetőséget.

A gyakorló orvosok közel negyedét kitevő háziorvosok, akik az egész lakossággal és annak elhízott részével napi kapcsolatban állnak, ilyen strukturált ajánlást eddig nem kaptak. Ezt a hiányt most pótolni kívánjuk. Az ennél is több információt igénylő olvasók a bő irodalomjegyzékből is meríthetnek.

\section{Módszerek}

A szakmai forrásokat fóleg a képviselt hazai társaságok korábbi munkaanyagai, aktuális nemzetközi (elsősorban európai és USA-beli) szakmai irányelvek, igényes irodalmi összefoglalók (randomizált kontrollált tanulmányok, metaanalízisek) adják, lehetőség szerint a hazai viszonyokra és egészségügyi ellátórendszerünkre való adaptálással.

Igyekezetünk szerint az elhízással elsősorban mint önálló entitással foglalkozunk, nem érintve azokat a megbetegedéseket, amelyekhez gyakran társul. A kórképet leegyszerüsítetten energetikai és következményes metabolikus problémaként közelítjük meg. Nem foglalkozunk az evészavarokkal (binge eating disorder, bulimia, anorexia stb.) sem.

\section{Az elhízás meghatározása}

Az elhízás minden esetben a zsírszövet (sejtszám és sejtméret) mennyiségi megnövekedését jelenti. Elsődlegesen alkalmazott mérőszáma a (méterben kifejezett) testmagasságból és a (kilogrammban megadott) testtömeg négyzetének hányadosából számított index, a BMI [kg/ $\mathrm{m}^{2}$ ], de fontos a derékkörfogat (haskörfogat) is, amely megbízható képet nyújt a zsigerek közötti zsírdeponálódás méretéról, mert metabolikus és cardialis szempontból ez a legveszélyesebb. A derék/has körfogatot a felső csípőlapát és az alsó bordaív szintje közötti távolság felénél kell mérni. A WHO besorolása szerint alkalmazott kategóriákat és ezek egészségi relevanciáját az 1. táblázat mutatja $[4,5]$. Figyelembe kell venni a BMI nem kizárólagos értékelhetőségét is, mert erős izomzat esetén is magas lehet az értéke. A magyar lakosság etnikailag nagyjából homogén, így az ázsiai embereknél megállapított alacsonyabb határértékeknek nálunk kicsi a relevanciája [6].

A test zsírtartalma több megbízható módszerrel is meghatározható: a bioimpedancia alapján vagy $D E X A$
1. táblázat $\mid$ Az elhízás cardiovascularis veszélyeztetettsége a BMI- és a derékkörfogat-kategóriák szerint $[4,5]$

\begin{tabular}{lll}
\hline Érték & Kategória & Veszélyeztetettség \\
\hline BMI $\left(\mathrm{kg} / \mathrm{m}^{2}\right)$ & & \\
\hline$<18,5$ & Alultáplált & Fokozott \\
$18,5-24,9$ & Normális & Kevés \\
$25-29,9$ & Túlsúly (pre-obesity) & Fokozott \\
$30-34,9$ & Elhízott I. (grade/class) & Nagy \\
$35-39,9$ & II. & Igen nagy \\
$40 \leq$ & III. & Extrém nagy \\
\hline Derékkörfogat $(\mathrm{cm})$ & & \\
\hline Férfi $<94$ & & Kevés \\
$94-102$ & & Jelentős \\
$>102$ & & Veszélyes \\
\hline Nó $<80$ & & Kevés \\
$80-88$ & & Jelentős \\
$>88$ & & Veszélyes \\
\hline
\end{tabular}

$\mathrm{BMI}=$ testtömegindex

(dual-energy X-ray absorptiometry) segítségével, pletizmográfiával, deutérium segítségével, izotópos módszerrel [7]. Klinikai jelentőségû a szervezet zsírmentes tömege (fat-free mass), amelynek változása a legmegbízhatóbban informál a testsúlycsökkentő kezelés eredményességéről, a csont, az izomzat arányairól, így akár fontos motiváló tényező lehet. Korábban gyakrabban használták a börredô vastagságának mérését a testfelület meghatározott 3-7 pontján vagy a testmagasság köbével képzett ponderális indexet és a (cm-ben megadott) magasság és a (kg-ban kifejezett) testtömeg különbségéből képzett Broca-indexet.

\section{Az elhízás etiológiája}

Ebben a munkában leegyszerúsítetten csak azzal az energetikai kérdéssel foglalkozunk, amikor az elhízás oka a tartósan pozitív energiamérleg. Ezt elsősorban a többletenergia bevitele okozza, a nagyobb, energiadúsabb ételadagok, a reklámok hatása a táplálkozásra, valamint az utóbbi évtizedekben a populáció fizikai aktivitásának csökkenése a munkafolyamatok, a közlekedés gépiesedése, az épített környezet átalakulása, a szabadtéri mozgáslehetőségek beszúkülése miatt, amit obesogen környezetnek nevezünk [5].

Nem foglalkozunk az elhízás olyan okaival, amelyek az endokrin rendszer zavaraira (például Cushing-betegség, hypothyreosis), bizonyos (pszichiátriai vagy diabetes elleni) gyógyszerek mellékhatásaira, a dohányzás elhagyását követô testtömeg-gyarapodásra vagy genetikai tényezókre vezethetők vissza, bár a testméreteket akár 40-70\%-ban genetikai faktorok határozhatják meg [8]. 


\section{Az elhízás epidemiológiája}

A túlsúly és az elhízás a XX. század második felében vált népbetegséggé (obesity pandemic). Évtizedekkel ezelőtt az akkori orvosképzésben csak mint tünetet, esetleg esztétikai, mobilitási problémát említették, nem eléggé felismerve és hangsúlyozva a kóroki jelentőségét. Elterjedése az utóbbi évtizedek egyik legnagyobb epidemiológiai kihívása a társadalom, a gazdaság és az egészségügyi ellátórendszer számára [9]. Az utcákon látható, egyre több túlsúlyos ember nagy része a rendelőkben és kórházi osztályokon is megfordul, immáron betegként. Az elöregedô társadalomban sok problémát jelentenek az egyre nagyobb számú, többnyire multimorbiditásban szenvedő elhízottak [10].

A testsúly folyamatos, az életkor előrehaladtával történő emelkedését általában normális, élettani jelenségnek tartják, ennek mértéke kb. 0,5 kg/év anélkül, hogy az érintettek észrevennék ennek okát.

$\mathrm{Az}$ antropometriai paraméterek meghatározása általában nem kötelező (vagy ritkán betartott) előírás az egészségügyi ellátás során, még kevésbé az ún. egészséges populációban.

Az elhízás globális „versenyében” hazánk előkelő helyen áll [9]. A magyar lakosság elhízása elsősorban az utóbbi évtizedek jellegzetessége, az elmúlt 30 évben a prevalencia drámaian nőtt. A BMI-értékek alapján besorolva, az 1980-as évek közepén a 18-34 év közötti férfiaknak csupán az 5\%-a volt elhízott, 30 évvel késóbb már a 18\%-uk, míg a 35-60 éves korosztályban 14\%-ról 34\%ra nőtt, 60 év fölött 18\%-ról 39\%-ra emelkedett az arányuk. Nőknél ugyanezen életkori kategóriákban a változások a következők voltak: 6\% és 16\%, 18\% és 39\%, a legidősebbeknél 23\% és 35\% [11-13]. A Magyarország Átfogó Egészségvédelmi Programja keretében elvégzett mérések alapján a nők 59\%-ának, a férfiak 46\%-ának volt kóros haskörfogata. A bioimpedanciás mérések mindkét nem 62\%-ában kórosan magas testzsírösszetételt találtak [14]. Összességében a mai magyar populációban férfiaknál a túlsúly 40\%-ban, az elhízás 32\%-ban van jelen, míg nőknél mindkét kategória közel 32\%-ban [12].

$\mathrm{Az}$ iskolai végzettség is befolyásolhatja az elhízás arányát. Hazai felmérés szerint a legkevésbé iskolázottak között lényegesen nagyobb arányú volt a túlsúlyosak és az elhízottak aránya. A felsőfokú végzettségúek között a férfiak legnagyobb része túlsúlyos, míg a nők körében az elhízás aránya a legalacsonyabb. A BMI és a derékkörfogat szerinti (hasi) elhízás a falvakban volt a legnagyobb arányú, különösen nőknél. A metabolikus betegségek jelenléte erősen korrelált a BMI-vel és inverz módon az urbanizáció mértékével [12].

A lakóhely is fontos lehet, mert a hegyekben élők között (USA, Ausztria) alacsonyabbnak találták az elhízottak prevalenciáját, viszont Magyarországon nincsenek magas hegyek $[15,16]$.
Komoly veszély, hogy az elhízás már a gyermekeknél is elöretört, bár aránya az utóbbi években Közép-Európában és hazánkban nem emelkedett [17].

\section{Az elhízás patológiai következményei}

Az elhízást olyan, krónikus megbetegedésnek kell tekinteni, amely a test kórosan megnövekedett zsírtartalmával jár. Ez a zsírsejtek strukturális változása (bypertrophia) mellett a szövetekben megnövekedett arányukat (hyperplasia) is jelenti, folyamatos gyulladást fenntartva, a még

2. táblázat $\mid$ Az elhízás patológiai következményei $[5,6]$

\begin{tabular}{|c|c|c|}
\hline \multirow[t]{4}{*}{$\begin{array}{l}\text { I. Metabolikus } \\
\text { szövődmények }\end{array}$} & Diabetes & $\begin{array}{l}\text { Metabolikus } \\
\text { szindróma }\end{array}$ \\
\hline & Inzulinrezisztencia & Dyslipidaemia \\
\hline & Köszvény & Hyperuricaemia \\
\hline & Tartós gyulladás & \\
\hline \multirow{3}{*}{$\begin{array}{l}\text { II. Cardiovascula- } \\
\text { ris kórképek }\end{array}$} & Hypertonia & Stroke \\
\hline & Coronaria-szívbetegség & $\begin{array}{l}\text { Pangásos szívelégte- } \\
\text { lenség }\end{array}$ \\
\hline & Vénás thromboembolia & \\
\hline \multirow{3}{*}{$\begin{array}{l}\text { III. Légzőszervi } \\
\text { megbetegedések }\end{array}$} & Asthma & Hypoxia \\
\hline & Alvási apnoe szindróma ( & OSAS) \\
\hline & Hipoventilációs szindróm & \\
\hline \multirow[t]{4}{*}{ IV. Daganatok } & $\begin{array}{l}\text { Nyelőcső-, vékonybél-, va } \\
\text { máj-, epehólyag-, hasnyál }\end{array}$ & $\begin{array}{l}\text { astagbél-, végbél-, } \\
\text { mirigy-, vesedaganatok }\end{array}$ \\
\hline & Leukaemia, lymphoma, n & nyeloma multiplex \\
\hline & $\begin{array}{l}\text { Nőknél: endometrium, m } \\
\text { emlő }\end{array}$ & éhnyak, petefészek, \\
\hline & Férfiak: prosztata & \\
\hline V. Osteoarthritis & A térd és a testet tartó na & gyízületek fájdalma \\
\hline \multirow{4}{*}{$\begin{array}{l}\text { VI. Gastrointesti- } \\
\text { nalis }\end{array}$} & Epehólyag-megbetegedés & sek \\
\hline & Zsírmáj ( non-alcobolic fat & ty liver disease) \\
\hline & Gastrooesophagealis reflu & \\
\hline & Sérv & \\
\hline \multirow{7}{*}{$\begin{array}{l}\text { VII. Urogenitalis } \\
\text { és reproduktív } \\
\text { szervek }\end{array}$} & Vizeletvesztés & Terhességi diabetes \\
\hline & Szabálytalan menstruáció & Infertilitás \\
\hline & Hirsutismus & Polycystás ovarium \\
\hline & Hypertonia & Praeeclampsia \\
\hline & Vetélés & Nagy méretú magzat \\
\hline & Velöcső-rendellenességek & Magzati distressz \\
\hline & Szülési rendellenességek & Császármetszés \\
\hline \multirow{2}{*}{$\begin{array}{l}\text { VIII. Pszichés és } \\
\text { szociális zavarok }\end{array}$} & Alacsony önértékelés & Szorongás, depresszió \\
\hline & Stigmatizáció & $\begin{array}{l}\text { Munkahelyi és } \\
\text { elhelyezkedési } \\
\text { problémák }\end{array}$ \\
\hline \multirow{6}{*}{$\begin{array}{l}\text { IX. Egyéb } \\
\text { kórképek }\end{array}$} & \multicolumn{2}{|c|}{ Idiopathiás intracranialis hypertonia } \\
\hline & Proteinuria & Lymphoedema \\
\hline & Nephrosisszindróma & \\
\hline & Bőrfertőzések & \\
\hline & Komplikációk anaesthesia & esetén \\
\hline & Periodontalis megbetege & dések \\
\hline
\end{tabular}


nem minden részében tisztázott hatásmechanizmusú vazoaktív anyagok (adipokinek) kóros szekréciója mellett. Az elhízásban számos gyulladásos mediátor mutatható ki, és ezeknek patológiai jelentőségük van $[5,18]$. Az elhízottak bélflórájában mikrobiom-változásokat írtak le, de ma még nem tudjuk biztosan, hogy ezek okai vagy következményei az elhízásnak [19]. Az elhízással oki öszszefüggésbe hozható kórképeket a 2. táblázat foglalja össze $[5,6]$.

\section{Az elhizás gazdasági terhei}

Magyarországon is az egészségügyi kiadásoknak egyre nagyobb hányadát költik az elhízással és a vele szoros oki kapcsolatban álló betegségek kezelésére. Az egészségbiztosító finanszírozási adatai alapján becsülve, az elhízott vagy túlsúlyos betegek ellátásának költsége a teljes E-Alap kiadásainak kb. 15\%-át, a bruttó hazai termék (GDP) közel 1\%-át teheti ki [20].

\section{Az elhízott beteg orvosi vizsgálata}

Az elhízott beteg gyakrabban fordul orvoshoz, többnyire más problémáival, ugyanakkor sokuknál nehéz ezt a témát tapintatosan szóba hozni. Némely beteg sértésnek veszi, mások nem mernek erről beszélgetést kezdeményezni az orvossal. Kiváló gyakorlati tanácsokkal szolgál a Canadian Obesity Network ún. $5 A$ megközelítése, amelyet a 3. táblázat szemléltet [21, 22].

Az orvosi kezelés formája nemcsak a BMI- és haskörfogatértéken alapul, hanem a kialakult patológiás állapot különböző stádiumai szerint kell a beavatkozás formáját és intenzitását megtervezni. A mindennapi klinikai gyakorlatban nagyon jól használható az Edmonton Obesity Staging System. Ebben 0-3 stádiumot (stage) különböztetnek meg, és ezek alapján javasolhatók a különböző diagnosztikus és obszervációs lépések, illetve terápiás beavatkozások [21].

A beteg vizsgálatának fontos, célszerüen a bevezető része az elhízás kialakulásával, a motiváció felmérésével kapcsolatos interjú. A javasolt kérdéseket és az elvégzendő diagnosztikus lépéseket a 4. táblázat részletezi.

3. táblázat $\mid$ Az $5 A$ módszere és fázisai az elhízás kezelésében [22]

\begin{tabular}{ll}
\hline ASK & $\begin{array}{l}\text { Kérjünk engedélyt, hogy a testsúlyáról és a változtatás } \\
\text { készségéról beszélgethessünk a beteggel. }\end{array}$ \\
\hline ASSESS & $\begin{array}{l}\text { Határozzuk meg az egészségügyi veszélyeztetettséget } \\
\text { (rizikót) és a testsúlygyarapodás potenciális okát. }\end{array}$ \\
\hline ADVISE & $\begin{array}{l}\text { Adjunk tanácsot az elhízás veszélyeiról és a kezelési } \\
\text { lehetóségek elónyeiról. }\end{array}$ \\
\hline AGREE & $\begin{array}{l}\text { Jussunk egyetértésre a testsúlycsökkentés reális } \\
\text { elvárásairól, a viselkedési, életmódi célokról. }\end{array}$ \\
\hline ASSIST & $\begin{array}{l}\text { Segítsük, támogassuk a motivációt és az akadályozó } \\
\text { körülmények feltárását, biztosítsunk oktatást és ehhez } \\
\text { való forrásokat, kérjünk konzultációt más szakorvostól, } \\
\text { tervezzük és szervezzük meg a követést, a kontrollokat. }\end{array}$ \\
\hline
\end{tabular}

4. táblázat $\mid$ Az elhízott beteg anamnézisének felvétele és a javasolt vizsgálatok [5]

Táplálkozási anamnézis

- A táplálkozási szokások (gyakoriság, mennyiség, időzítés) felmérése

- Az étkezési zavarok (például bulimia, éjszakai evés) kizárása - Hízott-e 20 éves korától 10 kg-nál többet?

\section{Megbetegedések}

- Fennáll-e diabetes, hypertonia, vagy utal-e erre gyanú?

- A fentiek előfordulása a családban

- Volt-e epeköve, epehólyag-betegsége?

- Depresszió, mentális betegségek jelenléte

- Nơknél: a menstruációs ciklusra és a menopauzára vonatkozó kérdések

Gyógyszerelés

- Aktuális és korábbi

- Dohányzás (elhagyása)

- Napközben gyakran elalszik-e?

Fizikai aktivitás

- Sportolás (jellege, mennyisége, gyakorisága; korábban és aktuálisan)

- Fizikai munka végzése, munkakör, otthoni tevékenységek - Mozgásszegény életmód?

Motiváció, változtatási szándék

- Korábbi testsúlycsökkentési próbálkozás?

- Miért akar fogyni?

- Kész-e megváltoztatni étkezését, életmódját?

- Ételeinek elkészítéséhez van-e elég ideje, pénze?

- Hajlandó-e sportolni, milyen sportot, van-e hozzá elég pénze?

- Kap-e családi, baráti, munkahelyi támogatást?

- Miért voltak sikertelenek/sikeresek a korábbi fogyókúrái?

Fizikális vizsgálatok

- Testtömeg, derékkörfogat és magasságmérés, a BMI számítása

- Vérnyomásmérés (megfelelő méretű mandzsettával)

- EKG (szükség esetén)

Laboratóriumi vizsgálatok (minimálisan)

- Éhomi vércukor

- Lipidprofil (össz-, HDL- és LDL-koleszterin, triglicerid)

- Szérumhúgysav

- Májfunkciók

- TSH (eltérés esetén a pajzsmirigyhormonok)

- Gyanú esetén: endokrinológiai vizsgálatok

CV-rizikó felmérése

Hasi ultrahang (NAFLD gyanúja esetén)

Alvásdiagnosztikai laboratóriumi vizsgálat (OSAS gyanúja esetén)

$\mathrm{BMI}=$ testtömegindex $; \mathrm{CV}=$ cardiovascularis $; \mathrm{EKG}=$ elektrokardiográfia; $\mathrm{HDL}=$ magas sűrûségű lipoprotein; $\mathrm{LDL}$ = alacsony sűrûségű lipoprotein; NAFLD = nem alkoholos zsírmájbetegség; OSAS = alvási apnoe szindróma; TSH = pajzsmirigy-stimuláló hormon

\section{Az elhízás lépcsőzetes kezelése}

Az elhízás fokától és a beteg állapotától függően többnyire lépcsőzetes kezelésre van szükség, amely az életmódi változtatásokat (fokozott fizikai aktivitás), táplálkozási tanácsokat (diéta), az esetleges gyógyszeres vagy sebészeti kezelést tartalmazza. Hosszabb távon törekedni kell a negatív energia-egyensúly elérésére, ami csök- 
5. táblázat |A kezelés lépcsői [5]

\begin{tabular}{|c|c|c|c|}
\hline \multirow[t]{2}{*}{ BMI, $\mathrm{kg} / \mathrm{m}^{2 *}$} & \multicolumn{2}{|c|}{ Derékkörfogat* } & \multirow{2}{*}{$\begin{array}{l}\text { Társbetegség } \\
\text { diabetes** }\end{array}$} \\
\hline & $\begin{array}{c}\text { férfi }<94 \mathrm{~cm} \\
\text { nô }<80 \mathrm{~cm}\end{array}$ & $\begin{array}{c}\text { férfi } \geq 94 \mathrm{~cm} \\
\text { nó } \geq 80 \mathrm{~cm}\end{array}$ & \\
\hline $25,0-29,9$ & É & É & $\mathrm{E}_{ \pm} \mathrm{Gy}$ \\
\hline $30,0-34,9$ & É & $\mathrm{E}_{ \pm} \mathrm{Gy}$ & $\mathrm{E}_{ \pm} \mathrm{Gy} \pm \mathrm{M}^{* *}$ \\
\hline $35,0-39,9$ & $\mathrm{E}_{ \pm} \mathrm{Gy}$ & $\mathrm{E}_{ \pm} \mathrm{Gy}$ & $\mathrm{E}_{ \pm} \mathrm{Gy} \pm \mathrm{M}$ \\
\hline$\geq 40,0$ & $\hat{E}_{ \pm} \mathrm{Gy} \pm \mathrm{M}$ & $\hat{E}_{ \pm} \mathrm{Gy} \pm \mathrm{M}$ & $\hat{E}_{ \pm} \mathrm{Gy} \pm \mathrm{M}$ \\
\hline
\end{tabular}

BMI = testtömegindex; É = életmódváltás (étrend és fizikai aktivitás); Gy = gyógyszeres kezelés jöhet szóba; $\mathrm{M}=$ mútéti beavatkozás jön szóba

kentett energiabevitellel, fokozott fizikai aktivitással érhető el, szükség esetén magatartásterápia alkalmazása mellett. Fontos a reális célok kitüzése és a folyamatos kapcsolattartás, annak tudatosítása, hogy a testsúlymenedzsment élethosszan tartó folyamat, és már 5\%-os testtömegcsökkenés is érezhetően tudja javítani az egészségi állapotot $[5,23]$. A beteggel meg kell beszélni a kezelés lépcsőit, ezeket az 5. táblázat szemlélteti [5].

\section{Az energiaszükséglet meghatározása}

$\mathrm{Az}$ étrend és a fizikai aktivitás tervezéséhez számszerú adatokat kell figyelembe venni. Az öröklött és az alkati tulajdonságok keretein belül a testsúly alakulását az energiafelhasználás és felvétel egyensúlya befolyásolja.

Az energiaszükséglet elsősorban az alapanyagcserétől függ (ez az energiaszükséglet kb. 60-70\%-a), ami éhező, semleges hőmérsékletű helyen élő férfiaknál átlagosan 4,2, nőknél 3,8 kJ/testtömegkilogramm/óra, és szorosan korrelál a zsírmentes testtömeggel, elsősorban a vázizomzattal. (A korábban elterjedt, de laikuskörökben még ma is elsődlegesen használt kalória értékének átszámítása: $1 \mathrm{kcal}=4,2 \mathrm{~kJ} ; 1 \mathrm{~kJ}=0,24 \mathrm{kcal}$.) Tehát az alapanyagcsere egy átlagos méretü felnőtt ember esetében óránként kb. $70 \mathrm{kcal}$, így energiaszükséglete - a kevesebb energiafelhasználást igénylő alvást is figyelembe véve - napi kb. $1600 \mathrm{kcal}(6700 \mathrm{~kJ})$. A szellemi munka energiafelhasználása csekély, kb. 300-400 kcal többletet ad az alapanyagcseréhez. Az ülö foglalkozású ember munkája, mindennapi mozgása további 350-500 kcal energia felhasználását jelenti [24].

Az energiaszükséglet pontos meghatározása helyett a mindennapi orvosi gyakorlatban be kell érni a becsléssel. A fentieket figyelembe véve így a $70 \mathrm{~kg}$-os, fiatal, könnyü fizikai munkát végző férfi napi energiaszükséglete kb. 2500-2800 kcal (10 500-12 000 kJ). Az élelmiszerek címkéjén a bevitt tápanyagok energiaértékének százalékát a 8400 kJ $(2000 \mathrm{kcal})$ napi energiaszükségletre vonatkoztatják, ez a referenciának tekintett 60 kg-os nó értéke.

A valós energiaszükségletet meghaladó bevitelt a fizikai aktivitás fokozásával lehet kompenzálni, ami átlagos körülmények között napi 500-1000 kcal-t (2100-4200
kJ) jelenthet. Ez fiatalkorban könnyen teljesíthető, az életkor előrehaladtával már kevésbé. Ezt az energiabevitelnél is figyelembe kell venni, megelőzve az életkor növekedésével gyakran együtt járó elhízást.

Az alapanyagcsere kiszámítására különböző táblázatok és algoritmusok ismeretesek, de ezek inkább laboratóriumi, mintsem napi orvosi körülményeket igényelnek. A táplálékok (fóleg a fehérjék) fajlagos hőhatása is bizonyos mértékű energiafelhasználással jár. Az izmok múködésével járó fizikai aktivitás viszont kifejezetten növeli az energia felhasználását, amit a különböző intenzitású mozgásformákra jellemző, az alapanyagcserére vonatkoztatott faktorokkal szoktak korrigálni (például az alvásé 1,0 ; az autóvezetésé: 1,4; a lassú sétáé: 2,8 ; a nehéz fizikai munkáé: 6,0; a teniszé: 4-6 stb.) [25].

\section{Az elhízottak fizikai aktivitásának fokozása}

Fiatalkorban, 20 éves korig, általában heti 6-7 óra testmozgásra van szükség. Ebből a későbbiekben engedni kell, kb. 10 évenként heti 1 órát, tehát 30 éves korban heti 5-6, 40 éves korban 4-5, 50 éves korban 3-4, 60 éves korban 2-3 óra testmozgás kívánatos, és ezt a heti 2 órát idősebb korban is fenn kell tartani, ügyelve a rendszerességre [24]. Gyaloglással napi tízezer lépés sport nélkül is teljesíthető elvárás [26].

Gyakorlatias kérdés, hogy mennyi legyen a sportban a rezisztenciaedzés, erőedzés aránya. Ez ellenállással szemben végzett gyakorlatokat jelent, súlyzók, erőgépek segítségével. A javasolt arány kb. 20\% erőedzés, 80\% dinamikus, állóképességi munka (futás, úszás, gyaloglás, evezés, kerékpározás, de lehet labdajáték, aerobik, tánc stb.). Az erôedzés intenzitását az egyéni igényekhez kell beállítanunk, inkább a kisebb ellenállás, nagyobb ismétlésszám kívánatos. Meg kell értetni - nem csak az elhízott - idős betegekkel is, hogy számukra is szükséges az erő a tartáshibák, az osteoporosis megelőzésére, tárgyak cipelésére, saját testük mozgatására, például betegként az ágyban vagy járókerettel [27].

Elhízott betegeknél elvárás a korábban megszokott energiabevitel korlátozása mellett a fizikai aktivitás növelése. Erről a korábban nem vagy már régóta nem sportoló, különösen már betegség(ek)ben szenvedő személyeknek szükséges konzultálniuk az orvosukkal. Az egyszerúbb mozgásformákon kívüli sportokban indokolt lehet ebben járatos szakember bevonása. Nemcsak a hirtelen megkezdett fizikai aktivitás esetleges rövid távú veszélyeit kell figyelembe venni, hanem inkább az elhízás hosszú távon prognosztizálható negatív hatásait [27, 28]. A mozgásszegény életmód következményei között nemcsak az elhízás szerepel, hanem a mozgatórendszer deformitása miatti tartáshibák, a munkavégző képesség általános csökkenése, idegrendszeri zavarok (neurosis, álmatlanság, vegetatív labilitás) is rontják az életminőséget, tehát ezek javulása is várható. 


\section{Mit és mennyit?}

A cardiovascularis edzés („kardio”) növeli a szív- és légzésfrekvenciát, nagy izomcsoportok repetitív igénybevételével.

A cardiovascularis edzés során tartósan elérendő pulzusszámot az ún. Karvonen-formula segítségével tudjuk kiszámolni. Az elérendő maximális frekvencia $\left(\mathrm{HR}_{\max }\right)=$ 220 - életkor [év]. Ennek legalább a 60-80\%-át kell elérni tartósan.

Rövid távon megvalósítható a heti összesen 150 perces vagy a legalább 5 napon át minimum napi 30 perces fizikai aktivitás, amelyből a gyors, lendületes séta (briskwalking) még a nagyon elhízottak számára is teljesíthető. Ez egészségeseknél pótolható 75 perc erőteljes edzéssel vagy a kettő arányos kombinációjával. Mindezek később heti 200-300 percre is növelhetők, a hosszú távon többnyire ismét jelentkező testsúlyemelkedés megelőzésére [29].

A 6. táblázat szemlélteti a sporttevékenység néhány formájának időegységek alatti energiaigényét [29]. A becsült adatok tájékoztató jellegúek, $72 \mathrm{~kg}$-os felnőttre vonatkoztatva. Keringési szempontból egészségeseknél még intenzívebben is végezhetố a sportolás, így több a felhasznált energiamennyiség, ami eredményesebben csökkenti a haskörfogatot, míg a rezisztenciaedzés növeli az izomtömeg mennyiségét. Az intenzívebb intervallumok közé kis szüneteket vagy kevésbé gyors gyakorlatokat lehet beiktatni [30]. Általánosságban akkor eredményesebb az edzés, ha kedvelt mozgásformára épül, tervezett beosztásban végzik, lehetőleg szabadtéren történik, baráti társaságban, ideértve akár a kirándulásokat.

Bizonyos tényezők előnytelenül befolyásolhatják a mozgás lehetőségét, az urbanizált lakókörnyezet, genetikai tényezők, megbetegedések és az azok miatti gyógyszerelés (testsúlyfokozó antidiabetikumok, antipszichotikumok, szívritmust befolyásoló kezelések stb.). Itt van helyük a sportolás elkezdésének fokozatosságára felhívó (házi)orvosi tanácsoknak, a megelőző bemelegítésnek, az izmok nyújtásának fontosságára, az esetlegesen már károsodott nagyízületek igénybevételére vonatkozóan. A sportolás mellett a napi aktivitás is egyszerúen fokoz-

6. táblázat | Egyes sport- és fizikai tevékenységek energiaigénye [29]

\begin{tabular}{lrc|cc}
\hline \multirow{2}{*}{ Aktivitás } & \multicolumn{3}{c}{ Energiafelhasználás } \\
\cline { 2 - 5 } & \multicolumn{2}{c}{30 perc } & \multicolumn{2}{c}{ l óra } \\
\cline { 2 - 5 } & kcal & \multicolumn{1}{c}{$k J$} & kcal & $k J$ \\
\hline Futás $(9 \mathrm{~km} / \mathrm{h})$ & 295 & 1240 & 590 & 2480 \\
Kerékpározás (18 km/h) & 295 & 1240 & 590 & 2480 \\
Úszás (lassú gyorsúszás) & 255 & 1070 & 510 & 2140 \\
Aerobik & 240 & 1000 & 480 & 2000 \\
Erőteljes gyaloglás $(8 \mathrm{~km} / \mathrm{h})$ & 230 & 970 & 460 & 1940 \\
Élénk kosárlabdázás & 220 & 920 & 440 & 1840 \\
Kemény kerti munka (például favágás) & 220 & 920 & 440 & 1840 \\
\hline
\end{tabular}

ható több gyaloglással, lépcsőjárással, tehát az autó- és a lifthasználat minimalizálásával.

A testsúlycsökkentő életmód türelmet és kitartást igényel. Tapasztalatok szerint kb. 7000-7200 kcal (30 000 kJ) többletenergia felhasználása eredményez $1 \mathrm{~kg}$ testtömegcsökkenést.

\section{Étrendi kezelés, diéta}

Az egészséges táplálkozás során a napi bevitt energiamennyiségen belül a makronutriensek fogyasztásra ajánlott alsó és felső határa: zsír (15-30\%), összes szénhidrát (55-75\%), fehérje (10-15\%) [31]. Fontos ismerni azonban a makronutriensek grammonkénti energiatartalmát: zsír: 9,3 kcal (39 kJ), szénhidrát: 4,1 kcal (17,2 kJ), fehérje: $5,4 \mathrm{kcal}(22,2 \mathrm{~kJ})$. A fehérjéknél, tekintettel az aminosavkomponensek tökéletlen elégésére a szervezetben, a szénhidrátokkal megegyező energiatartalommal lehet számolnunk. Betegeink gyakran figyelmen kívül hagyják az alkohol nagy energiatartalmát, amelynek égéshője 7,1 kcal (30 kJ) grammonként.

$\mathrm{Az}$ egyes termékek energiatartalma, összetétele csomagolt élelmiszereknél (jogszabály szerint) a termék csomagolásán megtalálható. Kötelező feltüntetni 100 gramm, illetve egy adag energia szénhidrát-, cukor-, zsír-, telítettzsír-, fehérje- és sótartalmát. Ez igen hasznos a tanácsadás és a fogyasztók eligazodása szempontjából. Hasznos segítséget adhatnak a tápanyagtáblázatok is, a hazai tápanyagtáblázatok azonban már elavultak. A bennük szereplő élelmiszerek egy része már eltûnt, vagy összetételük változott, és az új élelmiszerek még nem kerültek be.

A fogyáshoz tartósan negatív energia-egyensúlyt, célszerúen napi 500-750 kcal deficitet kell kialakítani, az energiaszükséglet $\mathrm{kb}$. 30\%-át. Ez átlagos testméretü nőknél napi 1200-1500 kcal, férfiaknál 1500-1800 kcal bevitelét feltételezi. Hatásos lehet bizonyos ételcsoportok (nagy szénhidrát- és zsírtartamú, kevés rostot tartalmazó ételek) fogyasztásának teljes elhagyása, még úgy is, hogy a napi energiabevitel nincs pontosabban meghatározva. Több zöldség és gyümölcs, nagy rosttartalmú ételek fogyasztása ajánlott, a snackek kiváltására. Gyakorlati tapasztalatok alapján az első lépcsőben az étkezések alkalmával elfogyasztott étel mennyiségének csökkentése is elég lehet, akár egymaréknyi mennyiségre. Mindez könnyebben megvalósítható a napi étkezések számának 4-5 alkalomra való emelésével.

Sokféle diétával történtek már eredményes próbálkozások, ezek felsorolásával és összehasonlításával itt nem foglalkozhatunk. Fontos, hogy a finomított szénhidrátok (cukrok) bevitelét minimalizálni vagy elhagyni szükséges. Rendezőelv lehet a minél kevesebb zsír, kevesebb és inkább összetett szénhidrátok, nagy rosttartalmú táplálékok fogyasztása. A legtöbb bizonyíték a sok (akár a 25-30\%) fehérjét tartalmazó étrendek eredményességére utal [32]. Fehérjéknél figyelembe kell venni a specifikus dinámiás, anyagcserét gyorsító hatásukat, de arra is fi- 
gyelni kell, hogy az étrendbe sovány, tehát elsősorban növényi eredetű fehérje kerüljön. A szintén fehérjeforrás húsok, húskészítmények zsírtartalma magasabb. Figyelembe kell venni azt is, hogy a fehérjék nagyobb telítettségérzetet eredményeznek, mint a szénhidrátok, ugyanakkor vesebetegség esetén ez az út nem járható. A már beteg személyeknél fontos a DASH (Dietary Approaches to Stop Hypertension) ajánlása szerint felépített étrend, a zöldségfélék és gyümölcsök fokozott fogyasztása [33].

Néhány praktikus tanácsot is adhatunk betegeinknek: általában nincs tiltott étel, csak az adag és a fogyasztási gyakoriság számít. Vásárláskor válassza a „light” alacsonyabb zsírtartalmú hús- és tejipari termékeket. A húsokról távolítsa el a látható zsírt. Kerülje a zsiradékban sült és a nagy cukortartalmú ételeket. A zsiradékot (vajat, margarint) csak vékonyan kenje kenyerére. Becsülje meg energiaszükségletét, vegye figyelembe, hogy az azonos energiaértékű zsír, fehérje, szénhidrát „hizlaló” hatása azonos. Csupán az étrend makrotápanyag-összetételének megváltoztatásától komoly eredményt várni hamis illúzió. Nagyon óvatosan kell fogadni az étrend-kiegészítő, fogyókúrás szerek, gyógyteák reklámjait, ellenőrizni kell valóságtartalmukat, gyakran tudománytalan állításaikat.

A fogyasztott ételek rendszeres monitorozása szükséges, táplálkozási napló vezetése mellett; ennek már számtalan „ $a p p$ ” formája terjedt el. Fontos segítség lehet a rendszeres (havi) konzultáció szakemberrel, dietetikussal.

Elhízott betegek számára fontos a Magyar Obezitológiai és Mozgásterápiás Társaságnak a VI. Magyar Kardiovaszkuláris Konszenzus Konferencián elfogadott étrendi ajánlása [32]. Egészségesek számára hazai közegben mérvadó forrás a Magyar Táplálkozástudományi Társaság ajánlása [34]. A nemzetközi ajánlások figyelembevételével dolgozta ki a Magyar Dietetikusok Országos Szövetsége az OKOSTÁNYÉR ${ }^{\circledR}$-t, amely hazai élelmiszerekből ad vizualizált, az arányokat is megjelölő táplálkozási ajánlást, felváltva a korábban divatos piramisformákat [35].

\section{Gyógyszeres kezelési lehetőségek}

Bár a szakmai irányelvek beillesztik a gyógyszerelést is az ajánlások közé, viszonylag kevés információt adnak a kezelőorvosnak a bevezetés idejére, a kezelés követésére [5]. A gyógyszeres kezelés jelenlegi lehetőségei igen korlátozottak. Magyarországon korábban csak az orlistat (Xenical $^{\circledR}$ ) volt forgalomban, amely a Streptomyces toxytricini által termelt lipsztatin hidrogenizált derivátuma. Hatására az elfogyasztott ételekben lévő trigliceridekben a zsírok nem képesek szabad zsírsavra és monogliceridekre hidrolizálni, így az elfogyasztott zsírmennyiség kb. 30\%-ának felszívódása gátlódik. Néhány éve került forgalomba a kétkomponensű Mysimba ${ }^{\circledR}$. A naltrexon opioidantagonista, amelyet alkohol- és opioidfüggőségről való leszoktatásban használnak, csökkenti az evés okozta örömfüggőséget, míg a bupropion major depresszióban, affektív zavarokban, dohányzásról való leszoktatásban vált be [36].

Nálunk nem forgalmazott, de elérhető több gyógyszer, így a fentermin mint étvágycsökkentő. Ezt a friss vizsgálatokban karcinogénnek bizonyult hatóanyagot tartalmazza a külföldön még mindig forgalmazott és hozzánk is behozott Adipex ${ }^{\circledR}$. Kombinációja az epilepsziaellenes készítmény topiramáttal került bevezetésre az amerikai piacra Qsymia ${ }^{\circledR}$ néven. A leggyakoribb szereket és alkalmazásukat a 7. táblázat tartalmazza. A kezelés so-

7. táblázat |A Magyarországon jelenleg elérhető gyógyszerek áttekintése

\begin{tabular}{|c|c|c|c|}
\hline Hatóanyag & Gyári név & Hatásmechanizmus & Alkalmazási ajánlás \\
\hline \multicolumn{4}{|c|}{ Magyarországon rendelhető } \\
\hline $\begin{array}{l}\text { Orlistat } \\
120 \mathrm{mg}\end{array}$ & $\begin{array}{l}\text { Alli }^{\circledR} \\
\text { Xenical }^{\circledR}\end{array}$ & Pancreaslipáz-inhibitor & Minden zsírtartalmú étkezéskor (max. napi 3×). \\
\hline $\begin{array}{l}\text { Naltrexon } \\
\mathrm{HCl} 8 \mathrm{mg}, \text { Bupropion } \\
\mathrm{HCl} 90 \mathrm{mg}\end{array}$ & $\begin{array}{l}\text { Contrave }^{\circledR} \\
\text { Mysimba }^{\circledR}\end{array}$ & & $\begin{array}{l}\text { bupropion } 360 \mathrm{mg}+\text { naltrexon } 32 \mathrm{mg} / \text { nap } 4 \text { héten át } \\
\text { feltitrálva, a terápiás adag eléréséig. Abbahagyandó, ha } 12 \\
\text { hét alatt nem sikerült } 5 \% \text {-os testsúlycsökkenést elérni. }\end{array}$ \\
\hline \multicolumn{4}{|l|}{ Elérhető, importálható } \\
\hline Lorcaserin & Belviq $^{\circledR}$ & $\begin{array}{l}\text { Szerotonin-2C-receptor- } \\
\text { agonista }\end{array}$ & $\begin{array}{l}\text { Abbahagyandó, ha min. } 5 \% \text { testsúlycsökkenést nem sikerült } \\
\text { elérni } 12 \text { heti kezeléssel. }\end{array}$ \\
\hline Fentermin & $\begin{array}{l}\text { Adipex-R Lomaira Suprenza } \\
\text { T-Diet Zantryl }\end{array}$ & & \\
\hline Topiramát & Topamax $^{\circledR}$ & Karboanhidráz-gátló & \\
\hline $\begin{array}{l}\text { Fentermin és } \\
\text { topiramát }\end{array}$ & Qsymia $^{\circledR}$ & $\begin{array}{l}\text { Szimpatomimetikus } \\
\text { fentermin és antikonvulzív } \\
\text { topiramát }\end{array}$ & $\begin{array}{l}\text { Indulás: } 3,75 \mathrm{mg} \text { fentermin + } 23 \mathrm{mg} \text { topiramát } 14 \text { napig, } \\
\text { majd folyamatosan emelhető a } 15 \mathrm{mg} \text { topiramát }+92 \mathrm{mg} \\
\text { fentermin adagra. Ha nem sikerült } 12 \text { hét alatt min. } 5 \% \text {-os } \\
\text { testsúlycsökkenést elérni, abba kell hagyni. }\end{array}$ \\
\hline Liraglutid $3 \mathrm{mg}$ & Saxenda ${ }^{\circledR}$ & GLPl-analóg & $\begin{array}{l}4 \text { hetes feltitrálási periódus. Ha összesen } 16 \text { hét alatt sem } \\
\text { sikerült min. } 4 \% \text {-os testsúlycsökkenést elérni, abbahagyandó. }\end{array}$ \\
\hline
\end{tabular}

GLP = glükagonhoz hasonló peptid 
rán az orvosnak követnie kell az alkalmazási elóírásokat, tekintettel kell lennie a mellékhatásokra és az egyéb gyógyszerekkel való esetleges interakciókra [23]. Hazai viszonylatban is nagyon fontos az ár, amely támogatás hiányában igen magas, kevesek számára megfizethető. A nagyszámú elhízott diabeteses beteg számára elérhetők az SGLT2-gátló készítmények (dapagliflozin, empagliflozin, ertugliflozin), a szintén testsúlycsökkentő hatású metforminnal való kombinációban is. Az ugyancsak komoly cardiovascularis előnyökkel járó GLPl-analógok - a kisebb dózisú liraglutid és az exenatid lixisenatid inkább ajánlhatók ennek a populációnak, természetesen megfelelő diabetológiai kontroll mellett [2].

\section{Metabolikus sebészeti beavatkozások}

Az elhízás sebészi kezelése nagyon sokat fejlődött az elmúlt évtizedekben, a mütétek száma ugrásszerüen megnőtt a kisebb megterhelést és emiatt kevesebb szövődményt eredményező laparoszkópos (minimálinvazív) technika bevezetése óta. Az egyes beavatkozások anyagcsere-folyamatokra kifejtett hatásának jobb megismeréséből nyert tapasztalatok alapján a korábbi felosztás már nem teljesen érvényes a mütétek (gyomorkapacitást csökkentő - restriktív és tápanyag-felszívódást csökkentő - malabszorptíp) hatására. A hangsúly a testsúlycsökkentésről eltolódott a mütétek metabolikus hatásaira, így a bariátriai sebészet elnevezést felváltja a metabolikus sebészet terminológiája [37]. Általánosságban elmondható, hogy a restriktív hatás a hatékony, a malabszorptív hatás pedig a tartós testsúlycsökkentés szempontjából lényeges. A jelenlegi legelterjedtebb laparoszkópos mútéteket mutatjuk csak be.

Az állitható gyomorgyürü beültetése a fogyást a táplálékfelvétel korlátozásával előidéző restriktín mütét, egyszerü technikai kivitelezhetőséggel. A korábban még nem ismert hosszú távú szövődmények (gyomorerózió, bandmigráció, nyelőcsőtágulat stb.) miatt jelenleg egyre kevesebben választják.

A 'laparoscopic gastric sleeve resection' (LGSR) a gyomornak ingujjhoz hasonló formában való reszekálása, döntően restriktív módszer a táplálékfelvétel korlátozására. A fundus eltávolításával csökken az itt termelődő grelin szintje, amelynek szerepe van az éhségérzet kialakulásában, így a mütétnek hormonális hatásmechanizmus is tulajdonítható. A mütét során a duodenumba vezetett, 12-16 mm külső átmérőjü szonda mentén kapocsvarró gépek segítségével vertikális reszekció történik az antrum egy részének meghagyásával, így mérsékelve a mútét után relatíve magas arányú gastrooesophagealis refluxot. Az utánkövetések szerint 30\% feletti a testsúlynövekedés és/vagy a reflux miatti mútétek aránya, 15-20\%-ot ér el a súlyos reflux, a Barrettmetaplasia [38, 39].

A 'laparoscopic Roux-en- $\Upsilon$ gastric bypass' (LRYGB) mütétjével kapcsolatban van a legtöbb tapasztalat. A gyomrot két részre osztják, subcardialisan 30-50 ml tér- fogatú tasakot képezve, majd 100-250 cm hosszú kacsot készítenek; a biliopancreaticus kacs 50-100 cm hosszú marad. A kis gyomor miatt restriktín, másrészt a vékonybél átrendezése miatt malabszorptín hatásmechanizmus vezet a testsúlyfelesleg 80-90\%-ának leadásához. A 2-es típusú diabeteses betegek 80-90\%-a mútét után normoglykaemiássá válik. Ennek hátterében a fogyás mellett hormonális hatások, valamint a vékonybél átrendezéséből származó biokémiai hatásmechanizmusok állnak. További előny, hogy a mútét jellegéből adódóan az esetek nagy részében meggyógyul a gastrooesophagealis reflux. A relatíve komplikált mútéti technika ellenére a hosszú távú jó eredmények és a szövődmények alacsony aránya miatt napjainkban ez a beavatkozás számít az arany standardnak a metabolikus sebészetben.

Perioperatív teendők: a mútét előtti kivizsgálás felméri a terhelhetôséget, és gyakran sor kerül pszichiátriai szakvizsgálatra, az elhízás okaként vagy következményeként felmerülő problémák felderítése céljából. A mütét utáni 2. napon - a nyelés kontrasztanyagos röntgenvizsgálata után - kezdődhet meg a per os táplálás, és a beteg a 3-5. napon távozhat a kórházból. Gyakran szükséges protonpumpa-inhibitor rendszeres szedése, $\mathrm{B}_{12}$ - és $\mathrm{D}$-vitaminszubsztitúció, esetenként $\mathrm{B}_{1}$-vitamin-, vas- és folsavpótlás. A mútéti szövődmények ritkák, a mortalitása 3-5 ezrelék körüli (varratelégtelenség, tüdőembolia és szívizominfarktus). Az intraabdominalis utóvérzések aránya 1-2\%. A gastric sleeve operáció után, perzisztáló reflux esetén szülkségessé válhat a Roux-en- $\Upsilon$ gyomorbypassra, esetleg duodenalis switchre való átalakító mütét, de akár a fiziológiás viszonyok visszaállítása is szóba jöhet.

A betegek mütét utáni gondozása komplex feladat, ideális esetben az érintett szakmák (obezitológus, belgyógyász, kardiológus, diabetológus, reumatológus, dietetikus, gyógytornász, pszichológus, metabolikus sebész) képviselőinek harmonikus együttmúködésével valósul meg $[40,41]$.

\section{Életmód- és magatartásterápia, viselkedési támogatás}

A testsúlycsökkentés bármely módszerének sikere nagymértékben függ a beteg mentális állapotától. Sok esetben szükség lehet pszichológus bevonására, akikból - legalábbis erre a területre, „beteganyagra” szakosodva - sajnos kevés van. Fontos a hosszú távú előnyök megismertetése, felcsillantva a későbbiekben elérhető jobb életminőséget, a kevesebb betegséget, az időskorban elérhető családi és mentális örömöket is.

A metabolikus sebészeti beavatkozásra szoruló beteget is támogatni kell pszichésen, megértetve vele, hogy az alacsonyabb BMI mellett végzett beavatkozás után nagyobb eséllyel kerülhetők el a további ortopéd sebészeti mütétek. Minél rövidebb ideig áll fenn a kóros elhízás és a 2-es típusú diabetes, annál valószínúbb, hogy a mútét után még elegendő béta-sejt marad a szénhidrát- 
anyagcsere helyreállásához. Ez adja a metabolikus sebészet másik perspektíváját $[40,41]$.

A „fogyókúrázó” betegek gyakran depressziósok lesznek, s ez gátolja az étrend betartását, a testsúlycsökkentést, ami egyéb megbetegedéseik miatt is szükséges lehet, veszélyezteti az eredményes gyógyszerelés hatását. Internetalapú támogatás, közösségi vagy „betegklubok” sokat segíthetnek [4l-45].

\section{Elhízott betegek az ellátórendszerben}

A korábban jó eredménnyel múködő, elhízottak kezelésére (is) szervezett centrumok többnyire megszűntek, áldozatul esve az egészségügy - jellemzően rövid távú fiskális szemléletû - átalakításainak. Az egyedüliként megmaradt Országos Obezitológiai Centrum egyben a hazai obezitológusképzés bázisát is jelenti [46].

Szükséges lenne, hogy a magyar egészségbiztosító legalább a morbid-obes betegeknél - befogadja a közfinanszírozásba a metabolikus sebészeti módszereket, lehetőség szerint nemcsak pénzügyi, hanem szakmai, minőségbiztosítási okokból is centrumokba szervezve. Közismert, hogy a mütéteknek ott van a legjobb eredményük, ahol sokat végeznek belőlük, és megfelelő multidiszciplináris team segíti a sebészt. Hazánkban egyelőre csak egy múködik európai mércék alapján, amelyet az EASO akkreditált [47].

Hasonló elven szükség lenne a gyógyszeres kezelés - legalább bizonyos BMI-érték feletti - finanszírozására is. Mivel az elhízás kezelésére alkalmazható gyógyszerek kevés országban élveznek (egészség)biztosítói támogatást, és alacsonyabb a megfizetésre hajlandó kereslet a betegek részéról is, ez kisebb potenciális piacot jelent a gyártóknak, akik így a fejlesztésben sem mindig eléggé motiváltak, és az utóbbi évtizedben lelkesen bevezetett szerek egy része is károsnak bizonyult, már néhány éves piaci szereplés után.

Sajnos csak kevés elhízott beteg tudja megfizetni ezeket a kezeléseket, ugyanakkor a társbetegségek - immár közfinanszírozott - kezelése összességében vélhetően drágább.

\section{Az elhízás prevenciója}

\section{A táplálkozási tényezők szerepe}

Sajnos az elhízás kezelése többnyire nem jelent sikeres vállalkozást, az elhízás megelőzése viszont eredményes lehet. A megelőzése már a születéskor elkezdődik. Az anya genetikája, életmódja, táplálkozási szokásai a meghatározók, később kiegészítve a családi szokások, a környezeti tényezők kockázatnövelő hatásával, annál kifejezettebben, minél fiatalabb korban érvényesülnek ezek a hatások. Ebben az értelemben a fogamzástól számított 1000 napnak van a legnagyobb jelentősége. A prevenciós programoknak ezeket a tényezőket is figyelembe kell venniük [48].
Csecsemókorban az anyatejes táplálás hiánya vagy 4-6 hónapnál rövidebb ideje, a szolid ételek korai bevezetése, a túlzott fehérje- és energiabevitel, illetve az első két évben bekövetkező gyors súlygyarapodás jelent rizikót a későbbi elhízásra [48, 49]. A várandós anya elhízása szignifikáns prediktora az utód elhízásának (fetal overnutrition hypothesis), táplálkozása epigenetikai faktorokon keresztül képes előre „programozni” a felnőttkori elhízásra való hajlamot. A metabolikus programozás csecsemőkorban akkor következik be, ha az élet első hónapjaiban túlzott mennyiségü a fehérjebevitel (early protein bypothesis), a szoptatás alatti táplálkozási intervenció pedig befolyásolhatja a programozódást [49]. A gyermek későbbi egészséges táplálkozása jó eséllyel tudja kivédeni a hajlamosító hatás érvényesülését $[48,49]$. Fontos tehát a várandós anyák megfelelő táplálkozása, alapvetően az egészséges felnőttek számára javasoltak szerint, szükség szerinti szupplementálással [34].

Az étkezések során, a korábban felsoroltak mellett, sok olyan egyszerúen betartható tanács adható, amelyek megelözhetik a szükségletet meghaladó tápanyagbevitelt. Ezeket már gyermekkorban is célszerü alkalmazni, a nevelésbe beillesztve. Például:

- Ne használja az étkezést időhúzásra, hosszabb beszélgetések helyszínéül.

- Terített asztalnál, ízléses környezetben étkezzen, de kerülje az étkezésre csábító helyzeteket.

- Figyeljen arra, mit és mennyit eszik (például otthon, tévénézés közben).

- Lassan egyen, és ne sokat (éhség-jóllakottság skála).

- Különböztesse meg a valódi éhséget az unalom, a stressz, a magány, a bünbánat stb. előidézte „éhségtől".

- Ne az étkezés örömét használja a feszültség oldására.

- Ne fantáziáljon kedvenc ételekről, ne csak azért egyen, mert itt az étkezés ideje.

- Ne nassoljon, egyen gyümölcsöt édesség helyett; az éhség egy falat barna kenyérrel vagy zöldséggel elnyomható.

- Igyon sok folyadékot, üdítő helyett ásványvizet.

Könyvtárnyi irodalma van a mediterrán étrendnek, amely a globalizáció miatt mára sokat változott. A hazai sajátosságokra adaptálva könnyen megvalósítható a burgonya heti háromszori, a vörös hús, húskészítmény, baromfi és hal heti kétszeri fogyasztása, az alacsony zsírtartalmú tejtermék napi kétszeri fogyasztása diófélék, magvak mellett. Minden főétkezéskor gyümölcs, kenyér, tészta, kuszkusz, rizs ajánlható. Beleilleszthető a hazai étrendbe az olívaolaj fogyasztása is, amely bizonyítottan előnyösen befolyásolja a vérzsírok profilját, csökkenti az összkoleszterin/HDL-koleszterin arányt, emeli az LDL- és a HDL-koleszterin szintjét. A sokat reklámozott pálma- és kókuszolajok sok telített zsírsavat tartalmaznak, inkább zsírok, mert szobahőmérsékleten megszilárdulnak, egészségvédő hatásuk kétséges. A mentális betegségek prevenciójában is jelentősek a táplálkozási tényezők. 


\section{A fizikai aktivitás jelentösége}

Az egész életen át végzett, életkorfüggő fizikai aktivitás mennyiségéről már volt szó korábban; fontosságát nem lehet eléggé hangsúlyozni, a családi modell itt is meghatározó. A hazai iskolai rendszerben a mindennapos testnevelés bevezetésével az utóbbi években sokat javultak a lehetőségek. Sajnálatos, hogy az ezen kívüli, nem versenyszerü sportoláshoz való hozzáférés nem egyformán biztosított minden gyerek (és persze felnőtt) számára. Szükséges lenne több helyszínen „fittséget felmérő” lehetőség kialakítása. Talán ez kapcsolódhatna az egészségfejlesztési irodák nem mindenütt kihasznált lehetőségéhez.

A mozgás igényének felkeltése, a naponta végzett rendszeres testmozgás lehetőségének megteremtése fontos családi és nevelési feladat, amelyet az elhízásra veszélyeztetett gyermekek kiszürésével és gondozásával kell kiegészíteni [49]. A különféle sportok jól kombinálhatók, és az életkorral ezek prioritása, gyakorisága változtatható. A családon kívül fontos minta az iskola és a lakóközösség is, amelyek prevenciós tevékenységeit koordinálni szükséges [50]. Partnerséget kell kialakítani a kormányzati szervekkel, a helyi szervezetekkel, akár a hitélet szervezőivel, hogy mindenki több fizikai aktivitást végezzen.

Nagyon fontos már gyerekkorban is a rendszeres, életkorhoz és megterheléshez igazított, megfelelő időtartamú és minőségü alvás biztosítása [51].

\section{A súlyfenntartás, -megôrzés problémái}

Eredményes testsúlycsökkentés, fogyókúra után, ha nagyjából fél év alatt a beteg elérte a kívánt eredményt, plató alakul ki, majd lassú visszahízás kezdődik. Ennek tempója lassabb gyógyszeres terápia mellett, a leglassúbb sebészeti beavatkozás után [30].

Az elhízás kezelése gyakran eredménytelen. Emiatt unortodox és nem bizonyítékokon alapuló kezeléseket is gyakran kínálnak a rászorulóknak, gyógynövényeket, homeopátiás, étrend-kiegészítő szereket. Az orvosoknak azonban ragaszkodniuk kell a bizonyítékon alapuló terápiákhoz, amelyek megbízhatóak és biztonságosak.

Önmagában a számokat, a BMI-értékeket nem szabad misztifikálni. Lehet ezek szerint elhízottnak számító egyén is egészséges, és normális BMI-vel is lehet valaki beteg. A cut-off pontok megtévesztők lehetnek, fontos a fizikai fittség; fat but fitt egyéneknél a testtömegcsökkentés nem sok előnyt tud adni $[52,53]$.

\section{Az „obesogen környezet” hatásának csökkentése}

Megoldásokat kell keresni a fejlettebb országokban az élelmezési környezet (food environment) módosítására, hiszen a konyhakész élelmiszerek elterjedése, a kevesebb mozgás ezt igényli $[54,55]$. Kormányzati (jogi és adóügyi) intézkedéseket igényel a hozzáadott cukor és só csökkentése, az élelmiszerek, üdítőitalok címkézése (food labelling), ahogy ez Magyarországon is megtörtént már, bár még nem tudjuk, milyen népegészségügyi hozadékkal.

\section{Technikai innovációk}

Napjaink technikája széles lehetőségeket kínál. Mód van a mozgás regisztrációjára és elemzésére akcelerométer (gyorsulásmérő), lépésszámláló, de akár mobiltelefon segítségével, az elfogyasztott ételeknek, beleértve a tápanyag-összetételnek a regisztrálására (applikációk és szoftverek formájában). A gyomorba épített elektronikus szenzor jeleket ad, amelyeket az egészségügyi személyzet (orvos) elemez, nyomon követve az étkezések időpontját, snackeket az étkezésre megengedett és nem megengedett periódusokban. Ennek ingerlésével telítettségi érzést lehet kiváltani, csökkentve az étvágyat, az élelmiszer-bevitelt [56].

\section{Az alapellátás lehetöségeinek kihasználása}

Még a leggazdagabb országoknak sincs olyan egészségügyi rendszerük, amely valamennyi elhízott és túlsúlyos egyént teljeskörüen el tudná látni. Elsősorban a megelőzésben van szükség a média segítségére; ez sajnos Magyarországon közel sincs kihasználva, több, kormányzat által támogatott megjelenésre lenne szükség.

Az elhízást a hazai orvostársadalmon belül még ma sem tekinti mindenki betegségnek, általában csak egy betegséget megelőző tünetnek. A magyar háziorvosok szakmailag sincsenek megfelelően felkészülve a testsúlymenedzsmentre, hozzáállásuk, felkészültségük, gyakran saját alkatuk befolyásolja tevékenységüket [57]. Az elhízáshoz vezető évtizedes folyamat gyakran a háziorvos szeme előtt zajlik le, aki tétlen szemlélője a testsúlynövekedésnek, az ennek hatására kialakuló metabolikus betegségeknek, halogatva vagy elmulasztva az időbeli beavatkozást [58]. Néhány egyszerü kérdés a táplálkozási szokásokkal és a napi fizikai aktivitással kapcsolatban sok információ forrása lehetne. A sport mint gyógyszer témában az elfoglalt háziorvos számára megszívlelendő, hogyan biztassa a beteget, ha csak két perce van: a fizikai aktivitás jelentőségét foglalja össze, adjon ajánlást, ismertesse a hasznos forrásokat, úgymint lépésszámláló, közösségi lehetőségek, weboldalak, videók, fotelban végezhető gyakorlatok, fitneszszakemberek elérhetőségei. Ha van öt perce a tanácsadásra, akkor a beteg hajlandóságának, az akadályok, a fizikai aktivitás elképzelhető fajtájának megbeszélését követően el kell magyaráznia az adott betegségben vagy annak kockázata esetén a sport előnyeit, és megbeszélni, hogyan tudná azt beépíteni a beteg a mindennapjaiba.

Az Egyesült Királyságban az utóbbi évtized egyik nagy és eredményes kezdeményezése volt a Counterweight Programme, képzett szakszemélyzet (dietetikusok, betegoktatók), orvosok, praxisnővérek vagy az ott önállóan 
dolgozó „nurse practitioner”-ek bevonásával [59]. Hazánkban is zajlott már ilyen program az Irányitott Betegellátási Rendszer keretében, de kisebb létszámban és csak 2 éves futamidőben, de rövid távon jó eredményekkel [60]. A magyar alapellátás nem halogatható reformjában erre a „praxisközösségek” tudnának keretet biztosítani.

\section{Anyagi támogatás: A szerzők a kézirat elkészítéséért anyagi támogatást nem kaptak.}

Szerzó munkamegosztás: R. I.: A koncepció kidolgozása, irodalomkutatás, szövegírás, a kézirat végső szerkesztése. A. P., B. I.: Szövegírás, irodalomkutatás. B. M., M. E., M. É., P. G.: Szerkesztés, irodalomkutatás, szövegírás. B. J. R., K. P., P. J., S. G.: Szövegírás. †P. Gy.: Közremüködés a kézirat kezdeti változatának szerkesztésében. B. Gy.: Irodalomkutatás, végső szerkesztés. A cikk végleges változatát valamennyi szerző elolvasta és jóváhagyta.

Érdekeltségek: A szerzőknek a cikkel kapcsolatos anyagi érdekeltségeik nincsenek.

\section{Irodalom}

[1] Evaluation of the outcomes of the Hungarian Health Care System, 2013-2015. [MÉRTÉK. A Magyar Egészségügyi Rendszer teljesítményértékelése 2013-2015.] Available from: https:// mertek.aeek.hu/jelentes-2013-15] [accessed: August 24, 2018]. [Hungarian]

[2] Professional guidelines of the Hungarian Diabetes Society. [A Magyar Diabetes Társaság szakmai irányelve.] Diabetol Hung. 2017; 25: 3-83.] [Hungarian]

[3] Professional guidelines of the Hungarian Hypertension Society. [A Magyar Hypertonia Társaság szakmai irányelve.] Hyperton Nephrol. 2018; 22(S5): S1-S36.] [Hungarian]

[4] Douketis JD, Paradis G, Keller H, et al. Canadian guidelines for body weight classification in adults: application in clinical practice to screen for overweight and obesity and to assess disease risk. CMAJ 2005; 172: 995-998.

[5] Yumuk V, Tsigos C, Fried M, et al., for the Obesity Management Task Force of the European Association for the Study of Obesity. European guidelines for obesity management in adults. Obes Facts $2015 ; 8$ : 402-424.

[6] Bray GA. Classification and evaluation of the overweight or obese patient. In: Bray GA, Bouchard C. (eds). Handbook of obesity. Clinical application. Third edition. Informa Healthcare, New York, London, 2008.

[7] International Atomic Energy Agency. Introduction to body composition assessment using the deuterium dilution technique with analysis of saliva samples by Fourier Transform Infrared Spectrometry. IAEA Human Health Series No. 12. Vienna, 2010.

[8] Willyard C. Heritability: the family roots of obesity. Scores of genes are implicated in obesity, but they cannot account for a family's predisposition to obesity. Are there other ways parents can influence their children? Nature 2014; 508: S58-S60.

[9] WHO Global Infobase Team. The SuRF report 2. Surveillance of chronic disease risk factors: country-level data and comparable estimates. World Health Organization, Geneva. Available from: https://apps.who.int/infobase/Publicfiles/SuRF2.pdf [accessed June 30, 2018]

[10] Mathus-Vliegen EM, on behalf of the Obesity Management Task Force of the European Association for the Study of Obesity.
Prevalence, pathophysiology, health consequences and treatment options of obesity in the elderly: a guideline. Obes Facts 2012; 5: 460-483.

[11] Bíró G. (ed.) First Hungarian representative nutrition survey (1985-1988). National Institute of Food Hygiene and Nutrition. [Az első magyarországi reprezentatív táplálkozási vizsgálat (1985-1988).] OÉTI, Budapest, 1992. [Hungarian]

[12] Rurik I, Torzsa P, Szidor J, et al. A public health threat in Hungary: obesity, 2013. BMC Public Health 2014; 14: 798.

[13] Erdei G, Kovács VA, Bakacs M, et al. Hungarian Diet and Nutritional Status Survey 2014. I. Nutritional status of the Hungarian adult population. [Országos Táplálkozás és Tápláltsági Állapot Vizsgálat - OTÁP 2014. I. A magyar felnőtt lakosság tápláltsági állapota.] Orv Hetil. 2017; 158: 533-540. [Hungarian]

[14] Barna I, Daiki T, Kékes E, et al. Five nine year results of "Comprehensive Health Screening of Hungary 2010-2020-2030". [Magyarország Átfogó Egészségvédelmi Szúrooprogramja 20102020-2030 (MÁESZ) eredményei 2010-2018, az első kilenc év.] Lege Artis Med. 2019; 29: 111-119). [Hungarian]

[15] Großschädl F, Stronegger WJ. Regional trends in obesity and overweight among Austrian adults between 1973 and 2007. Wien Klin Wochenschr. 2012; 124: 363-369.

[16] Voss JD, Masuoka P, Webber BJ, et al. Association of elevation, urbanization and ambient temperature with obesity prevalence in the United States. Int J Obes. 2013; 37: 1407-1412.

[17] Garrido-Miguel M, Cavero-Redondo I, Álvarez-Bueno C, et al. Prevalence and trends of overweight and obesity in European children from 1999 to 2016: a systematic review and meta-analysis. JAMA Pediatr. 2019; 173: el92430.

[18] Tilg H, Moschen AR: Adipocytokines: mediators linking adipose tissue, inflammation and immunity. Nat Rev Immunol. 2006; 6: 772-783

[19] Halmos T, Suba I. Physiological patterns of intestinal microbiota. The role of dysbacteriosis in obesity, insulin resistance, diabetes and metabolic syndrome. [A bélbakterióta élettani jellemzői és a dysbacteriosis szerepe az elhízásban, inzulinrezisztenciában, diabetesben és metabolikus szindrómában.] Orv Hetil. 2016; 157: 13-22. [Hungarian]

[20] Iski G, Rurik I. The estimated economic burden of overweight and obesity in Hungary. [Becslések a túlsúly és az elhízás hazai gazdasági terheiről.] Orv Hetil. 2014; 155: 1406-1412. [Hungarian]

[21] Kuk JL, Ardern CI, Church TS, et al. Edmonton Obesity Staging System: association with weight history and mortality risk. Appl Physiol Nutr Metab. 2011; 36: 570-576.

[22] Canadian Obesity Network. 5As of Obesity Management. Available from: http://www.obesitynetwork.ca/5As [accessed: April $11,2016]$.

[23] Rebello CJ, O'Neil PM, Horn DB, et al. Timing the discussion of antiobesity medications during obesity treatment. Obesity 2016; 24: 2027-2028

[24] Pavlik G. Physiology - Sport physiology. [Élettan - Sportélettan.] Medicina Könyvkiadó, Budapest, 2013. [Hungarian]

[25] Piepoli MF, Hoes AW, Agewall S, et al. 2016 European Guidelines on cardiovascular disease prevention in clinical practice. The Sixth Joint Task Force of the European Society of Cardiology and other societies on cardiovascular disease prevention in clinical practice (constituted by representatives of 10 societies and by invited experts). Developed with the special contribution of the European Association for Cardiovascular Prevention \& Rehabilitation (EACPR). Eur Heart J. 2016; 37: 2315-2381.

[26] Martos É. Recommendation on physical activity for healthy individuals. [Fizikai aktivitásajánlások egészségesek számára]. Metabolizmus 2018; 16: 59-63. [Hungarian]

[27] Apor P. The importance of physical activity. In: Császár A. (ed.) Obesitas. [A fizikai aktivitás jelentősége. In: Császár A. (szerk.) Obezitás.] TEVA, Debrecen, 2010; pp. 303-316. [Hungarian] 
[28] National Institutes of Health. NIH research model predicts weight with varying diet, exercise changes. NIH, Bethesda, MD, August 25, 2011. Available from: https://www.nih.gov/newsevents/news-releases/nih-research-model-predicts-weight-varying-diet-exercise-changes [accessed: April 11, 2020].

[29] Centers for Disease Control and Prevention. Physical activity for a healthy weight. CDC, Atlanta, GA, 2015. Available from: https://www.cdc.gov/healthyweight/physical_activity/ [accessed: April 11, 2020].

[30] Wewege M, van den Berg R, Ward RE, et al. The effects of highintensity interval training vs. moderate-intensity continuous training on body composition in overweight and obese adults: a systematic review and meta-analysis. Obes Rev. 2017; 18: 635646.

[31] Antal M. Nutritional requirements. In: Rodler I. (ed.) Updated nutritional facts. [Tápanyagszükséglet. In: Rodler I. (szerk.) Új tápanyagtáblázat.] Medicina Könyvkiadó, Budapest, 2005; pp. 19-70. [Hungarian]

[32] Bedros JR, Simonyi G, Pados Gy. Guidelines of obesity diet and excersise theraphy treatment. [Az elhízás diétás és mozgásterápiás kezelésének irányelvei.] Metabolizmus 2015; 13: 33-40. [Hungarian]

[33] Sacks FM, Svetkey LP, Vollmer WM, et al. Effects on blood pressure of reduced dietary sodium and the Dietary Approaches to Stop Hypertension (DASH) diet. DASH-Sodium Collaborative Research Group. N Engl J Med. 2001; 344: 3-10.

[34] Rurik I, Barna M, Bíró Gy. Nutritional recommendations for healthy adults. [Táplálkozási ajánlások egészséges felnőttek számára.] Metabolizmus 2018; 16: 54-58. [Hungarian]

[35] Organization of Hungarian Dietitians. Smart plate. New Hungarian nutritional recommendation. [Magyar Dietetikusok Országos Szervezete. OKOSTÁNYÉR® - Új magyar táplálkozási ajánlás.] Available from: http://mdosz.hu/uj-taplalkozasiajanlasok-okos-tanyer/ [accessed: April 11, 2020]. [Hungarian]

[36] Simonyi G, Pados Gy, Bedros JR. Naltrexone/bupropion fixed combination - a new drug for obesity. [Új lehetôség az elhízás kezelésére: a naltrexon-bupropion kombináció.] Metabolizmus 2016; 14: 360-364. [Hungarian]

[37] Wolfe BW, D'Alessio DA. Bariatric/Metabolic surgery for diabetes: Incorporating a powerful treatment into standard care. Obesity $2016 ; 24: 1205-1206$.

[38] Felsenreich DM, Ladinig LM, Beckerhinn P, et al. Update: 10 years of sleeve gastrectomy. The first 103 patients. Obes Surg. 2018; 28: 3586-3594.

[39] Genco A, Soricelli E, Casella G, et al. Gastroesophageal reflux disease and Barrett's esophagus after laparoscopic sleeve gastrectomy: a possible, underestimated long-term complication. Surg Obes Relat Dis. 2017; 13: 568-574.

[40] Mohos E, Schmaldienst E, Prager M. Quality of life parameters, weight change and improvement of co-morbidities after laparoscopic Roux Y gastric bypass and laparoscopic gastric sleeve resection - comparative study. Obes Surg. 2011; 21: 288-294.

[41] Naparstek J, Wing RR, Xu X, et al. Internet-delivered obesity treatment improves symptoms of and risk for depression. Obesity 2017; 25: 671-675

[42] Koenigsberg MR, Corliss J. Diabetes self-management: facilitating lifestyle change. Am Fam Phys. 2017; 96: 362-370.

[43] Halmy E. Experiences and results of complex treatment with extended ( 2 years) physical excersise in "life-style" clubs. [Életmód klubban szerzett tapasztalatok és eredmények mozgásterápiát tartalmazó hosszútávú (2 éves) komplex kezelés során.] Obesitol Hung. 2001; 2(S1): 12. [Hungarian]
[44] Wadden TA, Berkowitz RI. Advancing the revolution in the be havioral treatment of obesity. Obesity 2016; 24: 2029-2030.

[45] Driscoll S, Gregory DM, Fardy JM, et al. Long-term health related quality of life in bariatric surgery patients: a systematic review and meta-analysis. Obesity 2016; 24: 60-70.

[46] Hungarian Obesity Center. [Országos Obezitológiai Centrum, Budapest.] http://szentimrekorhaz.hu/hu/szolgaltatasaink/ fekvobetegellatas/belgyogyaszati-szakmak-matrix-szervezete/ 90-kardiometabolikus-centrum.html [accessed: April 11, 2020]. [Hungarian]

[47] Veszprém County Hospital. [Csolnoky Ferenc Kórház, Veszprém.] http://www.fogyasmutettel.hu [accessed: Dec 31, 2020]. [Hungarian]

[48] Barna M, Bíró Gy. Environmental factors increasing the risk of obesity principally in the first 1000 days of life. [Az elhízás kockázatát növelő környezeti tényezők, különös tekintettel az élet első 1000 napjára.] Metabolizmus 2018; 16: 223-227. [Hungarian]

[49] Symonds ME, Mendez MA, Meltzer HM, et al. Early life nutritional programming of obesity: mother-child cohort studies. Ann Nutr Metab. 2013; 62: 137-145.

[50] Kivelä J, Wikström K, Virtanen E, et al., on behalf of the Feel4Diabetes research group. Obtaining evidence base for the development of Feel4Diabetes intervention to prevent type 2 diabetes. A narrative literature review. BMC Endocr Disord. 2020; 20(Suppl 1): 140.

[51] Cash RE, Beverly Hery CM, Panchal AR, et al. Association between sleep duration and ideal cardiovascular health among US adults, National Health and Nutrition Examination Survey, 2013-2016. Prev Chronic Dis. 2020; 17: E43.

[52] Sharma AM, Campbell-Scherer DL. Redifining obesity: beyond the numbers. Obesity 2017; 24: 660-661.

[53] Apor P. More fittnes, better health - what family physicians can do? [A jobb fittség jobb egészség - mit tehet a háziorvos?] Családorv Fórum 2010; 5: 35-38. [Hungarian]

[54] Popkin B, Monteiro C, Swinburn B. Overview: Bellagio conference on program and policy options for preventing obesity in the low- and middle-income countries. Obes Rev. 2013; 14(Suppl 2): $1-8$.

[55] Freedhoff Y. The food industry is neither friend, nor foe, nor partner. Obes Rev. 2014; 15: 6-8.

[56] Busetto L, Torres AJ, Morales-Conde S, et al. Impact of the feedback provided by a gastric electrical stimulation system on eating behavior and physical activity levels. Obesity $2017 ; 25$ : 514-521.

[57] Rurik I, Torzsa P, Ilyés I, et al. Primary care obesity management in Hungary: evaluation of the knowledge, practice and attitudes of family physicians. BMC Fam Pract. 2013; 14: 156.

[58] Rurik I, Móczár Cs, Buono N, et al. Early and menopausal weight gain and its relationship with the development of diabetes and hypertension. Exp Clin Endocrinol Diabetes 2017; 125: 241-250.

[59] Counterweight Project Team, McQuigg M, Brown JE, Broom JI. Engaging patients, clinicians and health funders in weight management: the Counterweight Programme. Fam Pract. 2008; 25(Suppl 1): i79-i86.

[60] Móczár Cs, Borgulya G, Kovács E, et al. Could primary care dietary intervention combined with lifestyle changes be effective in the cardiovascular prevention? Acta Aliment. 2012; 41: 248256.

(Rurik Imre dr., Debrecen, Móricz Zs. krt. 22.; Postafiók 400, 4002 e-mail: Rurik.Imre@med.unideb.hu)

A cikk a Creative Commons Attribution 4.0 International License (https://creativecommons.org/licenses/by/4.0/) feltételei szerint publikált Open Access közlemény, melynek szellemében a cikk bármilyen médiumban szabadon felhasználható, megosztható és újraközölhető, feltéve, hogy az eredeti szerző és a közlés helye, illetve a CC License linkje és az esetlegesen végrehajtott módosítások feltüntetésre kerülnek. (SID_1) 